\title{
Civil Society Organization and Community Development, a Study of Enugu North Senatorial District of Enugu State. Nigeria (2007-2019)
}

\author{
Ugwuanyi, Kenneth Ekene', Nwobi Fidelia Obuteaku², and Chukwurah, Daniel Chi Junior ${ }^{3}$ \\ ${ }^{1,2,3}$ Department of Public Administration, Chukwuemeka Odumegwu Ojukwu University, Igbariam Campus, Anambra State, \\ Nigeria
}

Correspondence should be addressed to Ugwuanyi, Kenneth Ekene; ken4academic@yahoo.com

Copyright (C) 2022 Ugwuanyi, Kenneth Ekene et al. This is an open-access article distributed under the Creative Commons Attribution License, which permits unrestricted use, distribution, and reproduction in any medium, provided the original work is properly cited.

\begin{abstract}
Civil society organization and community development A study of Enugu north senatorial district of Enugu State (2007-2019). This study adopted three specific objectives: to ascertain the contributions of civil society organization to community road infrastructural development, to establish the linkage between civil society interventions and availability of potable water supply, and to examine the effect of civil society organizations activities in the improvement of community primary healthcare in Enugu North Senatorial District, Diffusion of innovation theory is the theoretical framework of analysis. Survey design utilized with population of 1,660,000 and sample size of 400. Data generated from primary and secondary sources. Descriptive statistics were used for data analysis and hypotheses were tested with chi-square with the aid of SPSS. The major findings are; civil society organization does contribute positively to community road infrastructural development, there is linkage between civil society organization and availability of potable water supply in Enugu north senatorial district and civil society organization's activities in Enugu north senatorial district did improve community primary healthcare significantly in Enugu north senatorial district. This study concludes that the citizens and other stakeholders are enjoined to advance the course of CSO's activities towards community development for the betterment of the communities, states and the society at large. It was recommended that public sector should make enabling laws that will guarantee further engagement of various CSOs as development driver of the state and government should sensitize the populace to be actively involved in most CSO's programmes.
\end{abstract}

KEYWORDS- Civil Society Organization, Community, Development, Enugu North Senatorial District, Nigeria

\section{INTRODUCTION}

The importance of civil society as an organization and a critical component of every society have become even more obvious in view of the obvious gap that has continued to widen between governance expectations and performance in democratic societies of Eastern Europe, Latin America and beyond. Even more, its relevance in development and political discourse in the last twenty years is not unconnected to the effect of democracy and democratization in developed and developing societies.

As a vital component of democratic societies, the civil society has been viewed in many quarters as an important agent for taming the monstrous tendencies of authoritarian regimes. The idea of civil society is to empower the people to act in ways that enhance the greatest happiness for the greater majority of the populace through enforcing governance inclusiveness, political accountability and quality implementation of government policies and programmes, hence citizens constant interaction with their government is the bottom-line of civil societies (Henry, 2008). United Nations Development Programme (UNDP)[13] sees the civil society as the third sector of the society besides the public sector and the private sector that interacts to bridge the gap between the profit motives of the private sector and the social welfare ideals of the public section. The UNDP's view on Civil Society Organizations is broad in the sense that non-governmental organizations are an integral part of the state whose activities borders on both collaboration and contention.

The collaborative nature of the activities of civil society organizations is in the fact that they support government policies and programmes that favours the people. Thus, one potent tool in the playbook of most political actors in government is to get the civil society to buy into their policies and programmes so as to enjoy the needed legitimacy and popular support which is a huge political capital both for the candidate and his or her political party. On the other hand, the contentious nature of the activities of civil society organizations is in the area of putting government in check, especially in areas where it is established that the particular policy or programme of the government will have negative consequences on the people. In this case, the civil society will arise as an agent of the masses to 'fight' the policy and where necessary, the government of the day. 
Despite the fact that civil society organization has been viewed in many quarters as an important agent for taming the monstrous tendencies of authoritarian regimes, every responsible government, especially a democratic government ought to recognize civil society organizations to facilitate closure of widening governance performance expectation gap from the populace. This view is aligned with gradual recognition and accommodation of civil society organizations as not just an integral part of the society but an extension of the structure of governance at the community level. Interview report of vanguard Newspaper[10] quoted a former commissioner for Human Capital Development and Poverty Reduction in Enugu State, Mr. Obinna Mbaeke, as affirming to government preparedness to inculcate town unions' administration as recognized structure of governance at community levels within the state.

\section{Statement of the Problem}

Civil society organization is relevant in areas where government failures are eminent. This is the gap that necessitated and prompted non state actors to action. In Enugu state for instance, many communities are in need, begging for government attention. In a report by Sahara Reporters[5] residents of Ette Community, in Igbo-Eze North Local Government Area of Enugu State, alleged that there is a total absence of governance or government presence in their community and that politicians only visit their community during electioneering campaigns.

The situation in Igbo-Eze North Local Government is a similar tale of woes in most parts of Enugu North Senatorial District. Evidence abounds of cases of acute developmental challenges in the forms of poor access roads, lack of primary healthcare facilities, dilapidated infrastructure, among others. This is despite the fact that one of its Local Government is playing host to Nigeria's most prestigious university, the University of Nigeria Nsukka. The acute shortage of basic social amenities like; safe drinking water, decent housing, quality health care facilities, electricity and communication facilities is a great concern to the people of the senatorial district thereby necessitating the urgent need to embark on this empirical investigation to assess the extent of engagement of civil society organizations in community development in Enugu north senatorial district of Enugu state.

\section{3. OBJECTIVES OF THE STUDY}

The broad objective of this study is to assess the effect of civil society organization in community development of Enugu North Senatorial District of Enugu State (20072019). Specific objective includes:

- To ascertain the contributions of civil society organizations to community road infrastructural development in Enugu North Senatorial District.

- To establish the linkage between civil society interventions and availability of potable water supply in Enugu North Senatorial District.
- To examine the effect of civil society organizations activities in the improvement of community primary healthcare in Enugu North Senatorial District.

\section{RESEARCH QUESTIONS}

These are the research questions meant for this study.

- How do civil society organizations contribute to community road infrastructural development in Enugu North Senatorial District of Enugu State?

- What is the linkage between civil society intervention and availability of potable water supply in Enugu North Senatorial District of Enugu State?

- What is the effect of civil society organizations activities in the improvement of community primary healthcare in Enugu North Senatorial District of Enugu State?

\section{HYPOTHESES}

These are the null hypotheses drafted for this research study.

- Ho Civil society organizations have no contributions to community road infrastructural development in Enugu North Senatorial District.

- Ho There is no linkage between civil society intervention and availability of potable water supply in Enugu North Senatorial District

- Ho Civil society organizations activities has no effect in the improvement of community primary healthcare in Enugu North Senatorial District

\section{Significance OF THE STUdy}

This empirical study shall be theoretical and practical significance.

Theoretically, this study would contribute immensely to the wealth of knowledge relating to civil society organization and community development. Other researchers in related work will find data generated from this study very useful as they could build on the findings in furthering research in this area of knowledge .Practically, the findings of this study would serve as a guide to the state and non state actors, development partners and civil society organization leaders on how they could practically execute their development agenda within their chosen communities for overall improvement of people's lives and society at large by using the findings and recommendations of this work judiciously.

\section{SCOPE OF THE STUDY}

The focus of this study is on Civil Society Organization and Community Development with specific attention to Enugu North Senatorial District of Enugu state. The time frame for the study covers the periods between 2007 and 2019. The justification for this time frame is to reflect the eight-year 
tenure of Governor Sullivan Chime of Enugu State and the four-year first tenure of Governor Lawrence Ifeanyi Ugwuanyi also of Enugu state. The variable constitute residents of the various communities studied, specifically those who have lived in the communities for upwards of five years.

\section{CONCEPTUal Clarification}

\section{A. Civil Society Organization}

The origin and evolution of the concept, civil society has not been unanimously documented. Most writers refer to its origin to the pre-state era when man is in his state of nature. In those era, man has no legal institution controlling its affairs, therefore every of its engagements are controlled by themselves which entrenched popular sovereignty with the people.

Man subsequently surrendered their individual rights to form a government which controlled all their activities with high expectations of taking care of their welfare, protect the weak from intimidations of the mighty and improve their standards of living. It is instructive to state here that man's inability to utilize the statutory institutions of the state to meet his expectation as it affects his freedom, security and welfare, created a gap that civil society organizations have come to fill. This has equally informed the surge in the importance of civil society organizations as non state actors in the journey to sustainable human development (Greer, Wismar, Pastorino and Kosinska [3]).

In the last two decades beginning from the late 1990s, civil society organizations have been gathering much impetus, this could be evidenced with the high number of civil society organization, the expansions of range of their engagements ranging from educating the populace on their civic responsibilities, monitoring and evaluation of state policies to check it's expected impact on the masses and pose strong resistance where the policy intention and expected outcome is perceived to be negative towards the masses and improve on quality of living of the greater populations by initiating projects, encouraging state and private partnership on one side and State and civil society organization partnership on the other side on policy for development initiation and implementation. Civil society Organization also embarks on maintenance of dilapidated infrastructure originally built by either the state institution, private organization or civil society organization themselves. Five decade back, civil society was a term known by and large to scholars, but currently it has become a globally debated concept. The critical role of advocacy and politics being played by civil society organization in relations to health in Europe has made its relevance indispensible. Health policy-makers within Europe clearly understood that undermining or not giving reasonable attention to civil society organization has great consequences and working in harmony with it has great gains (Greer, et'al 2017). Ikelegbe [14], did justice to specific roles of Civil Society Organizations in advancing the course for good governance by pointing out that civil society organization have been in the vanguard for transparency and accountability, kicking against corruption and financial negligence, advancing course for freedom of information and citizens access to vital governmental documents, encouraging public discourse on governance issues, exposing government excesses for public scrutiny and supporting legal litigations against public officials and agencies that are exposed in misconduct, financial recklessness and abuses of public offices. Kankya, Akandinda and Rwabukwali [15] saw civil society organizations as non-state, not-for-profit, voluntary organizations formed by people within the social sphere of civil society.

\section{B. Community Development}

Community norms, values and customs are becoming so visible in the behaviors' of individual members of the community. Most community leaders and socio cultural based civil society organization continues to advance course for community members' compliance to accepted community norms, values and customs within their jurisdiction. This could be attributed to why many persons could predict correctly the community of others via their public behavioral display.

Some scholars shifted attention from viewing development from physical infrastructure to man with strong argument that for real development to take place, man must be seen as epicenter for development. Amirize (1999) as cited in Doreen and Oroworukwo[2] ) stated that development proceeds from the inside and then manifests on the outside in the standard and quality of what people say, do and think. Any development in an individual or a community which does not reflect in the enablement of the quality of speech, action, behavior and thinking of the people is a mare charade. Rodney (1974) as cited in Onyekwelu,[18] saw development from the level of the individual and that of the society as a whole. Aroh [1] pointed out that the concept of community development is undoubtedly one of the oldest and most popularly acclaimed vehicles for the transformation of most societies all over the world. Community development should be the concern of all stakeholders looking at its' direct positive impact on community members and the larger society alike. Community members should play crucial role in the development of their community. The community identifies a need, takes action and participates together towards achieving that goal. It is through this action that the community becomes more vibrant economically and socially. Community development should be very visible with some specific changes in its environments and lives of community members. Udu and Onwe[19], concord with this view by affirming that community development has to do with the elimination of such limiting circumstances of life as poverty, hunger, ignorance, sickness and fear, in a bid to bring about improvement in the standard of living of a people. Rubin and Rubin (2001) (as cited in Udensi, Udoh, Daasi \& Igbara, [20]), stated that community development is visible when people make stronger the tier within their neighborhoods, put up their own structure to offer an enduring capacity for problem solving and building 
social networks. Such community members with requisite skills and abilities to devise developmental plans and pursue its execution vigorously for the overall good of community members encourages speedy development of their various communities.

\section{Civil society organization contribution to community road development}

Civil society organization and road construction is as old as man. In developing countries like Nigeria community road are first created by the community leadership, especially in rural areas. The community members embarks regularly on community services at an agreed date and time to map out new roads using local equipments like hoes, cutlass, digger, shovel etc with strict sanctions to those that did not come to work. In some communities, the mobilization for community road construction is usually organized through age grade system or rotational system amongst villages within a community. They apply the above listed local instruments to remove tries on the road, create local drainage and cut down strong wood for bridges were necessary.

As development began to widen, wealthy and good spirited individual began to spring up, and develop interest in the abysmal state of the community road thereby becoming the sponsors of most civil society organization at the community level and beyond. In developed countries of the world, the government took the responsibility of planning for the road network of the local and urban area. Adejumobi (1991), as cited in Nwobashi, \& Itumo[17] reported that in Enugu state, the town unions' economic resilient provided them the impetus to construct network of roads within their domains, established schools and health centers, provided potable water and took care of the wellbeing of their members without government intervention. According to Vanguard Newspape[7] relieve came the way of the people of Uke in Idemili North Council of Anambra state as one of their sons, Chief Tochukwu Kpajie, put smiles on their faces by construction of a major road in the community, saving them from years of agony of bad roads.

\section{Civil society organization's intervention in potable water supply}

It has been constantly advocated that man should have access to, safe, clean and sustainable water at all time because of its essential place for healthy society. Most communities in developing countries are still experiencing acute shortage of safe, clean and sustainable drinking water supply. According to Un-Water Global Analysis and Assessment of Sanitation and Drinking-Water[9], In rural areas and urban areas about $42 \%$ and $75 \%$ of households have access to safe water. This is one of the reasons that made Nigeria not to meet up with the Millennium Development Goal (MDG) target of $75 \%$ coverage for improved drinking-water and $63 \%$ for sanitation amenities by the year 2015. Poor access to safe drinking water have affected the citizens of such developing countries badly, especially the children.

The higher need for safe, clean and sustainable drinking water and the huge gap created by the government in the provision of this essential service to their citizens is a contributor to the need for this study.

\section{E. Civil Society Organization in the improvement of community primary healthcare}

The concept of Primary Health Care in Nigeria[22], stated that the concept of health care (PHC) was formulated by the 134 countries that meet at the Alma-Ata conference in Russia on September12th 1978 which was organized by the World Health Organization. Primary health care is a part of the three tier system of health care in Nigeria which are the tertiary, secondary and primary health care which are manned by federal, state and local governments respectively.

In developed and developing countries, provision of social services such as healthcare and health service delivery has been pivot role of which Civil Society Organizations have been constantly playing. No doubt some Civil Society Organizations provides various forms of support to communities including health, religious, educational, literary, agricultural and social development. Civil Society Organizations still have major challenges that build up from government inability to provide quality services to her citizenry (Kankya, et el )[15].

In the last decade, the activities of civil society organization in provision of health services have risen to quite commendable height both in developed and developing countries (Clayton, Oakley \& Taylor, 2000). Adejumobi (1991) (as cited in Nwobashi, \& Itumo[17] ) also observed that the state-of-art maternity centre constructed by town unions in Udi local government area of the state received no government assistance. On 27th of January 2005, the world health organization and United Nations International Children's Emergency Fund (Unicef)[12] announced in (WHO) website the reception of grant totaled ten million united state dollars (US\$ 10 million) from The Bill and Mellinda Gates Foundation to accelerate eradication efforts on Monovalent Oral Polio Vaccine destined for Egypt, which was a critical part of the strategy to end poliovirus transmission by the year of 2005. According to Berlan and Shiffman (2011) as cited in Kanthor, Seligman, Dereje and Tarantino[16], noted that increased citizen voice on health issues can inform providers about consumer needs and preferences. The above suggests numerous critical impact of civil society organization locally and globally.

\section{THEORETICAL FRAMEWORK}

\section{Diffusion of Innovation Theory}

This study is based on "Diffusion of innovation theory" as the theoretical framework of analysis. The diffusion of innovation theory is propounded by Rogers E. M.[23]. The diffusion of innovation theory is traced to have its origin from communication. Its target is to bring to limelight how within a time a communicated behaviour, idea or information diffuses or absorbed by a targeted population. Adoption here means that a person does something differently than what they had previously. The answer to adoption could be clear and easy if the person distinguish 
the behaviour, idea, product or information as new or modern, it is by this process that diffusion is achievable. Divergent stages are applicable in a bit to diffuse information, idea or behaviour into the society which are: Innovator, Early adopter, Early majority, Late majority and Laggard

\section{Methodology}

\section{A. Research Design}

This study utilized a survey research design because of the information needed for this investigation. It involves the collection of data (Respondents' opinion, from selected sample, study the sample for the purpose of making generalization about the entire population.

\section{B. Area of the Study}

This study is carried out in Enugu North Senatorial District of Enugu State of Nigeria. Enugu North Senatorial District is made up of six Local Government Areas. They are; IgboEze South, Igbo Etiti, Igbo-Eze North, Nsukka, Udenu and Uzo-Uwani Local Government Areas of Enugu State Nigeria.

\section{Population of the Study}

The population of this study is made up of males and females of Igbo Etiti, Igbo-Eze North, Igbo-Eze South, Nsukka, Udenu and Uzo-Uwani Local Government Areas of Enugu State Nigeria which makes up Enugu North Senatorial District. The population of this study is one million six hundred and sixty thousand $(1,660,000)$ male and female members of Enugu North Senatorial District.[6]

\section{Sample Size Determination and Sampling Technique}

The sample size is 400 which is selected from six local government areas of Enugu North Senatorial District using Taro Yamane.

\section{E. Sampling Technique}

Multi Stage sampling technique is adopted by the researcher for this study. The researcher first adopted purposive sampling technique to select participant of the study. Before administering questionnaire to a respondent, the respondent must meet the inclusion criteria which are;

- The person must be an indigene of the state

- The person must be up to eighteen years of age

- Must have been in the community for at least five years.

The researcher also used random sampling technique to select Enugu North out of the three senatorial districts of the Enugu State Nigeria, leaving out Enugu East and Enugu West Senatorial Districts of Enugu State Nigeria.

The researcher equally used random sampling technique to select five communities from each local government area of study. The whole communities were listed according to their local government area and with the help of research assistant five communities were randomly selected for the study. The researcher did the random selection to give equal representation to the entire senatorial district of the study.

\section{F. Sources of Data Collection}

The data were collected from secondary and primary sources. Secondary data were collected from books, journals, newspapers and internet materials in related research areas while the primary data were collected using questionnaire with two sections $\mathrm{A}$ and $\mathrm{B}$. Where $\mathrm{A}$ is introduction letter, $\mathrm{B}$ is personal data and the main questionnaire. Four hundred (400) sets of questionnaires were produced for this study. Sixty eight (68) questionnaires were distributed to these five (5) communities of Igbo Etiti local government area; Diogbe, Ochima, Ohebe Dim, Ohodo and Umuna. In the same way eighty four (84) questionnaires were distributed to these five (5) communities of Igbo-Eze North local government area; Etteh, Esodo, Umuitodo, Ezzodo and Umuozzi. Fourty eight (48) questionnaires were distributed to these five (5) communities of Igbo-Eze South local government area; Ihunowerre, Unadu, Nkalagu Obukpa, Ovoko Agu and Iheakpu Awka. One hundred (100) questionnaires were distributed to these five (5) communities of Nsukka Local government area; Obimo, Ibagwa-Ani, Edem, Okutu and Opi-Agu. Sixty (60) questionnaires were distributed to these five (5) communities of Udenu local government area; Obollo-Etiti, Amalla. Umundu, Ezimo Agu and Imilike Agu. Fourty (40) questionnaires were distributed to these five (5) communities of Uzo Uwani local government area; Igga, Nrobi, Nkpologu, Nkume and Akpugu-Ezedike.

The researcher wrote a letter to community leadership executive informing them of the researcher's intention of seeing them. The researcher was invited to their executive meeting which gave the researcher an opportunity to explain the importance of the study to the community, the researcher and the society at large, the expected duration and the pattern of distribution of the questionnaire and the researcher assured the executive of the confidentiality and total adherence to research ethics. After deliberation, approval was granted and village representatives volunteered to take the researcher to their respective villages for the administration of the questionnaire, in every house hold visited the researcher took time to explain the significance of the study, assured them of confidentiality and obtain their consent. The researcher explained the process of completing the questionnaire while some participant filled the questionnaire immediately after the researcher's explanation, some collected and asked the researcher to come back on a later date.

The above was applicable to communities in Igbo Etiti, Nsukka, Igbo-Eze South and Udenu Local Government Areas. However in Igbo-Eze North Local Government area, the researcher was referred to education and research committee of the communities. A meeting was fixed between the researcher and the education committee members where the research proposal was presented and approval obtained.In Uzo Uwani Local Government Area, the researcher administered the questionnaire through the community leadership due security challenges caused by Farmers and Headers clashes. 


\section{G. Administration and Retrieval of Research Instrument}

Four hundred (400) questionnaires were administered by the researcher to the thirty communities in six local government areas of Enugu North Senatorial District.

\section{$H$. Validity of Research Instrument}

The research instrument was first validated by my supervisor $\operatorname{Dr}(\mathrm{mrs})$ Nwobi, Fidelie.O and one other expert Prof. Ewuim, Ngozi. of the Department of Public Administration Nnamdi Azikiwe University Awka.

\section{Reliability of Research Instrument}

This study's reliability of the research instrument were obtained with the aid of pilot test. The questionnaires were subjected to pilot studies where twenty adults' members of Nsukka and Igbo-Eze South indigenes whose age ranges from below 30-51 above years participated. The result from the pilot test yielded positive result. This was to ensure the questionnaire guide meant the same thing to all the respondents. Cronbach's Alpha co-efficient of $r=\alpha .75$, which show that the instrument is greatly reliable having crossed the .45 minimum base. See the table below.

\section{J. Tools for Data Analysis}

SPSS is used for most of the data analysis

\section{DATa PReSentation AND ANALYSIS}

The collated data from respondents were presented, analyzed and discussed accordingly in this chapter. The Likert scale format was applied and questionnaire responses were analyzed while hypotheses were tested through the application of chi-square (x2) test. A theoretical mean value of 3 was taken as a criterion to judge the mean for the items in the respective sections. Therefore, any item in the instrument which had a mean that is equal or higher than 3 was taken as agreed, while the items that are less than 3 were taken as disagreed.

\section{A. Demographic Data of Respondents}

Gender: 152 male and 235 female participated in the research.

Table 2: Questionnaire items 6-10 response on CSO and provision of potable drinking water

\begin{tabular}{|l|l|l|l|l|l|}
\hline & CSO_Water1 & CSO_Water2 & CSO_Water3 & CSO_Water4 & CSO_Water5 \\
\hline Valid & 387 & 387 & 387 & 387 & 387 \\
\hline Missing & 0 & 0 & 0 & 0 & 0 \\
\hline Mean & 3.9406 & 3.5504 & 3.7261 & 3.7235 & 3.5633 \\
\hline Std.Dev & 1.06721 & 1.24235 & 1.40222 & 1.26267 & 1.44430 \\
\hline
\end{tabular}

Source: Field work 2021

CSO_Water 1-5 represent research questionnaire items on civil society organization and provision of potable drinking water in Enugu north local senatorial district of Enugu State from 2007-2019. Mean results =3.9406, 3.5504, 3.7261, 3.7235 and 3.5633 . This mean result that is up to 3 shows that the respondents agreed that civil society organization

\section{XiI. Data Presentation On The SubJect OF THE RESEARCH}

Research Question One

How do civil society organizations contribute to community road infrastructural development in Enugu North Senatorial District?

This question is targeted towards finding out how civil society organization contributes toward community road infrastructure.

Table 1: Questionnaire item1-5 response on how CSO intervenes on community road infrastructure.

\begin{tabular}{|l|l|l|l|l|l|}
\hline z & $\begin{array}{l}\text { CSO_R } \\
\text { oad } \\
1\end{array}$ & $\begin{array}{l}\text { CSO_R } \\
\text { oad } \\
2\end{array}$ & $\begin{array}{l}\text { CSO_R } \\
\text { oad } \\
3\end{array}$ & $\begin{array}{l}\text { CSO_R } \\
\text { oad } \\
4\end{array}$ & $\begin{array}{l}\text { CSO_ } \\
\text { Road } \\
5\end{array}$ \\
\hline Valid & 387 & 387 & 387 & 387 & 387 \\
\hline $\begin{array}{l}\text { Missin } \\
\text { g }\end{array}$ & 0 & 0 & 0 & 0 & 0 \\
\hline Mean & 3.6202 & 3.3902 & 3.5478 & 3.9044 & 3.6848 \\
\hline $\begin{array}{l}\text { Std. } \\
\text { Deviati } \\
\text { on }\end{array}$ & 1.35352 & 1.33901 & 1.32127 & 1.28912 & $\begin{array}{l}1.4571 \\
1\end{array}$ \\
\hline
\end{tabular}

Source: Field work 2021

CSO_Road 1-5 represent research questionnaire items on civil society organization intervention on community road infrastructure in Enugu north local senatorial district. Mean results $=3.6202,3.3902,3.5478,3.9044$ and 3.6848. This mean result that is up to 3 shows that the respondents agreed that civil society organization does contribute to community road infrastructure in Enugu North Senatorial district of Enugu State within 2007-2019.

Research Question Two

What is the linkage between civil society intervention and availability of potable water supply in Enugu North Senatorial District of Enugu State? This research question is meant to illicit response from the participant on how civil society organization provided potable drinking water in Enugu north Senatorial District of Enugu State. contribute to provision of potable drinking water in Enugu North Senatorial district of Enugu State within 2007-2019.

Research Question Three

What is the effect of civil society organizations activities in the improvement of community primary healthcare in Enugu North Senatorial District of Enugu State?

Here the researcher will display the response of the participant in relation to civil society organization activities 
towards improvement of community primary healthcare in Enugu North senatorial District of Enugu State.

Table 3: Questionnaire items 11-15 response on CSO on primary healthcare

\begin{tabular}{|l|l|l|l|l|l|}
\hline & $\begin{array}{l}\text { CSO_P } \\
\text { HC1 }\end{array}$ & $\begin{array}{l}\text { CSO_P } \\
\text { HC1 }\end{array}$ & $\begin{array}{l}\text { CSO_P } \\
\text { HC1 }\end{array}$ & $\begin{array}{l}\text { CSO_P } \\
\text { HC1 }\end{array}$ & $\begin{array}{l}\text { CSO_ } \\
\text { PHC1 }\end{array}$ \\
\hline $\begin{array}{l}\text { Val } \\
\text { id }\end{array}$ & 387 & 387 & 387 & 387 & 387 \\
\hline $\begin{array}{l}\text { Mis } \\
\text { sin } \\
\text { g }\end{array}$ & 0 & 0 & 0 & 0 & 0 \\
\hline $\begin{array}{l}\text { Me } \\
\text { an }\end{array}$ & 4.0698 & 3.7649 & 3.6796 & 4.0362 & 3.9509 \\
\hline $\begin{array}{l}\text { Std. } \\
\text { De } \\
\text { via }\end{array}$ & 1.22063 & 1.42662 & 1.33726 & 1.19963 & $\begin{array}{l}1.1806 \\
6\end{array}$ \\
\hline
\end{tabular}

Source: Field work 2021

CSO_PHC 1-5 means civil society organization primary healthcare questionnaire items one to five.

Mean results $=4.0698,3.7649,3.6796,4.0362$ and 3.9509.

This mean result that is up to 3 shows that the respondents agreed that civil society organization does participate in provision of primary healthcare services in Enugu North Senatorial district of Enugu State within 2007-2019.

\section{TEST OF HYPOTHESIS}

The hypotheses for this study will be tested using ChiSquare. SPSS is used as instrument for the test of the hypothesis.

Table 4. Chi-Square Statistics

Chi-Square Statistics

\begin{tabular}{llll}
\hline Variables & & & \\
& TT_CSORod & TT_CSOWatr & \multicolumn{1}{c}{ TT_CSOPHC } \\
\hline $\mathrm{Cv}$ & $115.036 \mathrm{a}$ & $185.119 \mathrm{~b}$ & $197.070 \mathrm{c}$ \\
& 15 & 13 & 14 \\
$\mathrm{Tv}$ & 24.2 & 27.6 & 25.8 \\
Asymp.Si & .000 & .000 & .000 \\
g. & & & \\
\hline
\end{tabular}

Source: field work 2021

$\mathrm{H} 01, \mathrm{X} 2 \mathrm{:} \mathrm{cv}=115.036 \mathrm{a}, \mathrm{df}=15, \mathrm{tv}=24.2, \mathrm{P}>.000$

$\mathrm{H} 02, \mathrm{X} 2 \mathrm{:} \mathrm{cv}=185.119 \mathrm{~b}, \mathrm{df}=13, \mathrm{tv}=27.6, \mathrm{P}>.000$

$\mathrm{H} 03, \mathrm{X} 2 \mathrm{:} \mathrm{cv}=197.070 \mathrm{c}, \mathrm{df}=14, \mathrm{tv}=25.8, \quad \mathrm{P}>.000$

Hypotheses

- Ho Civil society organizations have no contributions to community road infrastructural development in Enugu North Senatorial District.

- Ho There is no linkage between civil society intervention and availability of potable water supply in Enugu North Senatorial District

- Ho Civil society organizations activities has no effect in the improvement of community primary healthcare in Enugu North Senatorial District
Decision: The three null hypotheses were rejected looking at the fact that calculated values likened to $\mathrm{cv}$ are higher than table values likened to tv at significant level of $p=$ .000 .

\section{DISCUSSION OF FINDINGS}

Having distributed, collated and analyzed data of this study, the researcher found out that civil society organization do engage in community road infrastructural development in Enugu north senatorial district of Enugu state (2007 and 2019).

Tables 4.2.1 above showed the acceptable mean results $=3.6202,3.3902,3.5478,3.9044$ and 3.6848.

Similarly the following mean results $=3.9406,3.5504$, $3.7261,3.7235$ and 3.5633 of research question two in table 4.2.7 above have proofed that CSO do intervene greatly in the availability of potable water in Enugu North senatorial District within 2007 and 2019

In the other hands, the researcher found out that CSO was actively engaged in the improvement of community primary healthcare in Enugu north senatorial district (20072019).

Mean results of 4.0698, 3.7649, 3.6796, 4.0362 and 3.9509 of research question three in table 4.2.13 above is very supportive to this findings.

\section{SUMMARY OF FINDINGS}

Civil society organization does contribute positively to community road infrastructural development in Enugu north senatorial district (2007-2019).

There is linkage between civil society organization and availability of potable water supply in Enugu north senatorial district (2007-2019).

Civil society organization's activities in Enugu north senatorial district did improve community primary healthcare significantly in Enugu north senatorial district (2007-2019).

\section{Conclusions}

The findings of this study as enumerated above are very crucial to man as community roads play critical role to availability of most raw materials for industrial use and food for sustenance of man comes from the communities.

Potable water is very vital to sustenance of man as abject lack of same or availability of undrinkable water could lead to outbreak of one form of disease to another within the community.

Availability of primary healthcare at community level is very fundamental to having a healthy society. This is important because any community that don't have access to primary healthcare are prone to health complications at either secondary or tertiary health level as most of the diseases that ought to have been nipped at the board are abandoned.

Having noted crucially the finding of this study and UNDP postulations that civil society organization is the third sector of the society outside public and private sector, the citizens 
and other stakeholder are enjoined to advance the course of CSO's activities towards community development for the betterment of the community's, states and the society at large.

\section{RECOMMENDATIONS}

The researcher made the following recommendation;

The public sector should make enabling laws that will guarantee further engagement of various CSO as development driver of the state.

Government should sensitize the populace to be actively involved in most CSO's programmes as that will indirectly eschew political parochialism and encourages participatory political culture.

\section{REFERENCE}

[1] Aroh, C (2003) Community Development and mass mobilization in Nigeria: Concept and Approaches. Enugu Snaap Press Ltd.

[2] Doreen, K. \& Oroworukwo, N. (2014). Grassroots Perception and Participation in Community Development Programs in Etche Local Government Area. 4(16).

[3] Greer, S.L.,Wismar,M., Pastorino, G., \& Kosinska, M. (2017). Civil Society and HealthContributions and Potential: Denmark. WHO Regional Office for Europe, UN City, Marmorvej.

[4] Henry, V. (2008). Civil society and local development. Canada: Interacoes Campo Grande. 9(2), 229243.

[5] http://saharareporters.com/2021/02/08/sad-tales-enugucommunity-where-politicians-only-visit-during-electioncampaigns

[6] https://www.citypopulation.de/php/nigeria-admin.php

[7] https://www.vanguardngr.com/2021/01/succour-for-anambracommunity-as-philanthropist-builds-road/

[8] https://www.britannica.com/science/water

[9] https://www.unwater.org/publication_categories/glaas/

[10] https://www.vanguardngr.com/2017/02/enugu-govt-adopttown-unions-fourth-tier-govt/

[11] https://www.mayoclinic.org/healthy-lifestyle/nutrition-andhealthy-eating/in-depth/water/art20044256\#: :text=The\%20U.S.\%20National\%20Acade

[12] https://www.unicef.org/nigeria/water-sanitation-and-hygiene

[13]http://www.undp.org/cso/resource/policies/UNDPCSOPolicy. doc

[14] Ikelegbe, A., (2013). The State and Civil Society in Nigeria: Towards a Partnership for Sustainable Development: Benin City. Centre for Population and Environmental Development.

[15] Kankya, C., Akandinda, A. \& Rwabukwali, C., B. (2013). The role of civil society organizations (CSOs) in healthcare delivery system: A case study of child immunisation in Kabarole district, Uganda 5(8).1277-1288

[16] Kanthor, J., Seligman, B., Dereje, T., \& Tarantino, L., (2014). Engaging Civil Society in Health Finance and Governance: A guide for practioners. MD: Health finance \& Governance project, Abt Association inc.

[17] Nwobashi, H,.N. \& Itumo, A.(2019).Town Unions and Provision of Electricity in Rural Communities in Ebonyi State: A Focus on Selected Communities: IOSR Journal Of Humanities and Social Science (IOSR-JHSS) Volume 24(3) $63-73$
[18] Onyekwelu, R. (2020;1) Development theory and Administration. COOU: lecture note for Master students.

[19] Udu, L. E., \& Onwe, S. O.( 2016). Approaches to community development in Nigeria, issues and challenges: A Study of Ebonyi State Community and Social Development Agency (EB-CSDA).Journal of Sustainable Development. 9(1). doi:10.5539/jsd.v9n1p296

[20] Udensi, L., O., Udoh, O,.S., Daasi, G.L.K. \& Igbara, F.N. (2012). Community leadership and the challenges of community development in Nigeria: The case of Boki local government area, Cross River State: International Journal of Development and Sustainability. 1(3).912-923.

[21] UNDP (2014). A Guide to Civil Society Organizations working on Democratic Governance UNDP and Civil Society Organizations: A Practice Note on Engagement (2001), p. 1

[22] www.who.int/mediacentre/news/notes/2005/np03/en/

[23] https://sphweb.bumc.bu.edu/otlt/mphmodules/sb/behavioralchangetheories/behavioralchangetheori es4.html 